This item was submitted to Loughborough's Research Repository by the author.

Items in Figshare are protected by copyright, with all rights reserved, unless otherwise indicated.

\title{
Deterioration model and condition monitoring of aged railway embankment using non-invasive geophysics
}

\section{PLEASE CITE THE PUBLISHED VERSION}

https://doi.org/10.1016/j.conbuildmat.2018.03.066

\section{PUBLISHER}

(c) Elsevier

\section{VERSION}

AM (Accepted Manuscript)

\section{PUBLISHER STATEMENT}

This work is made available according to the conditions of the Creative Commons Attribution-NonCommercialNoDerivatives 4.0 International (CC BY-NC-ND 4.0) licence. Full details of this licence are available at: https://creativecommons.org/licenses/by-nc-nd/4.0/

\section{LICENCE}

CC BY-NC-ND 4.0

\section{REPOSITORY RECORD}

Gunn, David, J. Chambers, B. Dashwood, A. Lacinska, Tom Dijkstra, S. Uhlemann, R. Swift, et al.. 2018. "Deterioration Model and Condition Monitoring of Aged Railway Embankment Using Non-invasive Geophysics". Loughborough University. https://hdl.handle.net/2134/32860. 
Click here to download Figure: Gunn-Con-Build-Mat-MS-Revised-Changes-Accepted-28-Feb-2018-with-Figs.docx Const.+Build Mat.

1 Deterioration model and condition monitoring of aged railway embankment using non-invasive geophysics

2 *Gunn, D.A. ${ }^{1}$, Chambers, J.E. ${ }^{1}$, Dashwood, B.E. ${ }^{1}$, Lacinska, A. ${ }^{1}$, Dijkstra, T. ${ }^{2}$, Uhlemann, S. ${ }^{1}$,

3 Swift, R. ${ }^{1}$, Kirkham, M. ${ }^{1}$, Milodowski, A. ${ }^{1}$, Wragg, J. ${ }^{1}$ \& Donohue, S. ${ }^{3}$

$4 \quad 1$ - British Geological Survey, Nottingham, England.

52 -School of Architecture, Building and Civil Engineering, Loughborough University, formerly British Geological 6 Survey

73 - School Of Civil Engineering, University College Dublin, formerly School of Natural and Built Environment,

8 Queen's University, Belfast

$9 \quad$ * Corresponding author: e-mail: dgu@bgs.ac.uk; Tel. +44 (0) 1159363400

11 Abstract

Effective management of railway infrastructure is becoming increasingly reliant upon remote condition monitoring of geotechnical asset condition. Current monitoring approaches focus on confirmation of the morphological effects caused by subsurface processes driving deterioration. However, geophysical imaging offers new opportunities for 'predict and prevent' practices, providing access to monitoring internal property change patterns preceding these morphological responses. Geophysical methods utilize disturbances that propagate through and holistically sample earthworks and are especially suited to imaging the unique heterogeneity of aged embankments. In this case study, surface wave seismic surveys are interpreted to construct a stiffness ground model consistent with a heterogeneous embankment comprising local borrow materials. Time-lapse electrical resistivity imaging was also used to investigate and visualise ground water ingress and movement within this ground model. Ground water movement was shown to be highly dynamic, responding very quickly to local storm events with infiltration into the embankment within hours. Subsequent wetting and drying cycles throughout the embankment's lifespan have caused the dissolution, mobilisation and re-precipitation of soluble minerals within the fill materials. This process has driven the deterioration of the fill fabric, which is evidenced in thin sections by voids and localised rupture about in situ mineral growths. management practices of the future. 
Const.+Build Mat.

1 Introduction: Monitoring Heterogeneous Engineered Earthworks

\section{Construction and heterogeneity of aged railway embankments}

3 Much construction of the UK railway network commenced in the 19th century, during the formative years of the Industrial Revolution, (Skempton, 1996). Excavation of aged railway cuttings commonly employed large teams of navvies using driven wedges, horse-pulled ploughs, hand tools, and on the later railways such as the Great Central, steam-powered excavators (Brees 1841, Stevenson 1886, Skempton 1996). While the construction materials were influenced by the underlying geological formations, the engineering characteristics of fine-grained, stiff clay or weak mudstone formations favoured relatively easy excavation using these tools, hence, many aged railway earthworks comprise London Clay, Oxford Clay, Gault Clay, Mercia Mudstone and Lias Clay (Reeves et al. 2006). The absence of established practice resulted in embankment construction methods varying considerably between networks, often based upon the experiences of the chief

\section{Monitoring Challenges posed by aged infrastructure}

Earthworks assessment requires the determination of soil properties important for the evaluation of performance. Soil type, moisture, stress levels and strength control problems such as plastic deformation, heave, shear failure and mud pumping which lead to a loss of level and support (Perry et al. 2003). Repeated visual inspections are mostly used to identify embankment problems, essentially looking for morphological features that confirm movement or anomalous groundwater conditions (Perry et al. 2003). This approach is limited, for example because vegetation can often obscure signs of ground movement or the subsurface 
Const.+Build Mat.

ground and water conditions are not accessible, and consequently, slopes are perceived to fail 'rapidly' without displaying visible signs of distress. But, most common geotechnical monitoring approaches still involve displacement measurements of embankments, often following observations of morphological features associated with instability (Dunnicliff 2012). Surface and downhole tilt meters or extensometers are often deployed to assess the displacement profile with depth. Such approaches require boreholes and can be accompanied by groundwater level measurements using piezometers. These data inform stability analyses, aid risk assessments and may contribute to remedial design. However, these approaches include the expense of intrusive works, and implicitly accept the potential for failure, which does not honour the strict terms of 'early warning'.

Remotely sensed approaches are better suited for more rapid, cost effective network coverage of the morphological features currently used to define marginal condition. Satellite or ground based radar (LiDAR), robotic total stations and photogrammetry provide high resolution ground displacement information (Mazzanti 2012), but still essentially confirm the morphological response to underlying subsurface property (condition) changes that form earlier phases of asset deterioration. With no standard practice and no, or very poor, 'as built' documentation, capturing the representative heterogeneity in a ground model that will reliably predict progressive failure of aged infrastructure is especially challenging. However, geophysical imaging offers the opportunity to monitor longer term, internal property (condition) change patterns, potentially the precursors to the surface morphological responses currently defining 'failure'. These property change signatures offer a potential baseline against which internal condition thresholds can be identified and, used as early warning of future instability, would enable more progressive effects of climate and ageing stresses to be assessed (Gunn et al. 2015a, 2016a).

This paper presents combined rapid cone penetration and non-invasive geophysical methods for studying the spatial and temporal variations within an end-tipped Victorian embankment. Geophysical imaging methods include use of surface wave surveys (Gunn et al. 2015b, 2016a,b) and electrical resistivity tomography (ERT), (Chambers et al. 2014, Gunn et al. 2015a). These provide volumetric infill between boreholes to create a pseudo-3D embankment stiffness model, within which we attribute heterogeneous structures to end tipping 
Const.+Build Mat.

construction methods. A hydrogeological model is also presented for the embankment system, where using time lapse ERT images, dynamic ground water movement is visualised. In situ fracturing, heave, secondary mineralisation and de-structuring within the fabric of samples taken from the embankment provide further evidence of the long term deterioration driven by this groundwater movement. Hence, this paper raises the potential for new definitions of condition and deterioration based upon monitoring of internal properties and their changes using non-invasive geophysics. To this end, we present a condition monitoring framework based on geotechnical property metrics provided via imaged geophysical proxy.

\section{Study Site Investigation}

\section{Embankment Layout and Invasive Probings}

Our study site comprised a $140 \mathrm{~m}$ long section of the whole embankment located at East Leake on the former Great Central Railway (GCR) that extends $800 \mathrm{~m}$. The embankment was built up over the Branscombe Formation of the Mercia Mudstone Group in 1897 using local materials excavated from the tunnel cutting to the SW and the bridge cutting to the NE (Bidder 1900). The fill was end tipped and then compacted by subsequent movement of shunting locomotives and tipping wagons across the tipped material. The embankment has been subjected to several phases of site investigation from 2005 to 2011, which has included drilling beneath the ballast, collection of core samples, invasive probing and non-invasive geophysical surveying; the locations of boreholes, probings, point and line geophysical surveys are shown Fig. 1 . The study focused particularly on the section from $0 \mathrm{~m}$ to $140 \mathrm{~m}$ in Fig. 1, which included 8 MOSTAP samples taken beneath the ballast, through the embankment fill and into the underlying formation (approximately $7.0 \mathrm{~m}$ long). Rapid invasive probing also included static cone penetration tests (Meigh 1987), in which a cylindrical cone was pushed vertically into the ground at a constant penetration rate of $20 \mathrm{~mm}$ per second. During penetration, measurements were made of the cone resistance, the side friction against the cylindrical shaft and, in piezocone tests, the pore water pressure generated at penetration by the cone. 
Const.+Build Mat.

\section{Non-invasive Geophysical Surveys}

Non-invasive geophysical surveying at the site included electrical resistivity tomographic (ERT) imaging and surface wave surveys using continuous surface wave (CSW) and multi-channel analysis of surface wave

(MASW) methods. ERT is an established method for high resolution mapping of lithological variations (Shevnin et al. 2007) and changes in soil moisture (Cassiani et al. 2009; Brunet et al. 2010), and has contributed to previous railway stability assessments (Donohue et al. 2011; Gunn et al. 2015a). Chambers et al. (2014) detail the ERT layouts and methods used to map the fill materials and image groundwater movement in relation to their distribution throughout the embankment, which is summarised here to provide a site methodology guide. Similarly, surface wave surveys are an established method for characterising the shear wave velocity and stiffness of the shallow subsurface (Foti 2003; Rucker 2003), which are also suitable for railway earthwork assessment (Gunn et al. 2015b; Bergamo et al. 2016). Gunn et al. (2011a, 2016b) detail the CSW and MASW layouts and methods used to map the stiffness distribution throughout the embankment fill, again summarised here.

Permanent installation of ERT electrode arrays buried approximately $150 \mathrm{~mm}$ beneath the surface included a line parallel to the embankment (blue line in Fig 1) comprising 96 electrodes spaced at $1.5 \mathrm{~m}$ and a line over the embankment (red line from the East to West toe) comprising 32 electrodes at $1 \mathrm{~m}$ spacing. Field data were collected using the dipole-dipole configuration, with dipole widths (a) of $1-4$ times electrode spacing, and unit dipole separations ( $\mathrm{n}$ ) of a to 8 a. Overall, good quality data were available for the 2D inversions, which used a regularized least-squares optimization algorithm (Loke and Barker, 1995; Loke et al. 2003) to solve the forward problem using the finite difference method. Good convergence between the observed and model data was achieved as indicated by average RMS errors of 3.0\% (standard deviation 0.6\%). By applying appropriate temperature correction and petrophysical relationships linking resistivity to saturation, time-lapse, volumetric images of water movement and moisture content changes were constructed from repeated ERT surveys, following the methodology by Chambers et al. (2014). 
Const.+Build Mat.

Each CSW survey location utilised a controlled frequency, vertical oscillator and a small number of $4 \mathrm{~Hz}$ geophones (6 max). Phase differences between the ground motions on successive geophones were used to calculate wavelength and field dispersion curves, where wavelengths shorter than one third the shortest receiver spacing, (0.3 $\mathrm{m}$ for $1 \mathrm{~m}$ spacing at site) and longer than three times the largest receiver spacing, (15 $\mathrm{m}$ for 6-geophones) can be measured with CSW (Joh 1996; Menzies 2001). The MASW surveys utilised an impulsive sledge hammer source and longer geophone arrays of between $24-36 \mathrm{no} .10 \mathrm{~Hz}$ geophones spaced at either $0.5 \mathrm{~m}$ (array to $17.5 \mathrm{~m}$ ) or $1 \mathrm{~m}(35 \mathrm{~m}$ ). Complete section coverage (along $140 \mathrm{~m}$ ) was achieved by pulling along and re-locating each successive geophone array to follow on from where the previous array was recorded. The frequencies generated by the sledge hammer were limited to below $80 \mathrm{~Hz}$, whereas the CSW vibrator could generate frequencies from $5 \mathrm{~Hz}$ to $200 \mathrm{~Hz}$ and produce wavelengths as short as $0.5 \mathrm{~m}$ enabling characterisation of the subsurface within a similar depth interval. In both MASW and CSW methods the field dispersion curves were inverted from the field records to produce a velocity-depth profile for the shallow subsurface (Joh 1996, Foti 2003). The profile is referenced to the centre of the geophone array subgroup, whose records are used to construct the dispersion curve, up to 6 geophones for CSW and up to 9 geophones for MASW. The dispersion curve was interactively forward-modelled to determine the subsurface shear-wave velocity profile (Joh 1996, Foti 2003 \& Raines et al. 2011). The simplest method is attribution of a factored shear wave velocity (usually 0.93 times Rayleigh wave velocity) to a depth that is equivalent to a fraction of the Rayleigh wavelength, $\lambda$ (Joh 1996, Foti 2003). A factor of $\lambda / 3$ is most commonly used because a significant proportion of the particle motion in the ground associated with Rayleigh wave propagation is located approximately at this depth. The small strain stiffness is the product of the square of the shear wave velocity profile was estimated from the shear wave velocity-depth profile and a pseudo-3D model constructed from multiple profiles using an inverse-distance weighting. ERT and MASW surveys were undertaken along lines running parallel to the track (such as the blue line shown in Fig. 1). CSW surveys were undertaken at many locations across the crest of the embankment and just beneath the toe of the embankment flanks (green circles/triangles in Fig. 1). Further ERT surveys were also undertaken across sections of the embankment (red line). With higher resolution sampling, both the 
Const.+Build Mat.

heterogeneity of aged earthworks and the dynamic groundwater processes driving deterioration can be better

captured. The ERT and surface wave methods described, both support sub-metric vertical sampling, e.g.

enabling capture of the physical properties in the upper earthworks and lower ballast, where many railtrack problems begin, i.e. in the form of subgrade deformation and ballast pocket formation. Electrode spacing controls the horizontal sampling of the ERT imaging, which was as low as $2 \mathrm{~m}$ across the section within the ballast and upper earthworks but becomes coarser with increasing depths. The spacing between the CSW locations limited horizontal sampling to $10 \mathrm{~m}$, but MASW sampling via selection of the off lap-overlap between successive geophone - groups used to construct consecutive velocity profiles, was as low as $3 \mathrm{~m}$ across the parallel line along the embankment crest. Higher resolution sampling of the shallow subsurface makes these methods more robust to lateral effects, such as potential short-circuiting of current along the rails during ERT imaging, or interference from refracted events during shallow surface wave surveys. Current flow through the rails was found to be insignificant in both modelled simulations and field ERT measurements due to the very large ground to rail contact resistances presented by connecting sleeper-tie systems. Contact resistances were over $2 \mathrm{k} . \mathrm{Ohm}$ in places which resulted in $15 \%$ of the normal - reciprocal pair errors of $>5 \%$. While high contact resistances limit the injected current and reduce signal/noise quality, these effects are less significant at the closer dipole spacings used to image the very shallow zones in the embankment, where as shown in Fig. 2, sensitivity is at its greatest. The deeper zones of reduced sensitivity occur within the formation underlying the embankment below $5 \mathrm{~m}$ depth and also in the zones of higher resistivity fill to the NE. Location of electrodes at the slope toes extends the zone of higher sensitivity deeper into the core of the embankment, which is especially useful for tracking moisture infiltration into this zone. Refracted waves were seen to interfere with surface waves in the field records, but separate out in the phase velocity-frequency images, which enabled the fundamental Rayleigh mode to be distinguished as the lowest velocity event (Gunn et al. 2011b). The high frequency range of the CSW method also makes it especially suitable for identifying non-normally dispersive velocity profiles often encountered on ballasted railway tracks.

Figure 2. Lateral and vertical sensitivity to resistivity measurements. 
Const.+Build Mat.

The Great Central stopped running mainline trains on the 5th May 1969, and since then, ash and hawthorn with occasional elder and oak trees have matured over both slopes with roots growing into the crest of the embankment, shown conceptually in Fig. 3. Rainwater infiltrates directly into the crest, but is intercepted by the tree canopy before falling onto the mid-lower slopes. East - west runoff over a shallow local slope contributes to occasional flooding at the eastern toe following periods of persistent, heavy rain, such as after the $2006 / 7$ and $2007 / 8$ winters. Infiltration over a transect of the embankment was monitored from spring 2006 to winter of 2008 using an array of proprietary moisture content sensors placed $300 \mathrm{~mm}$ beneath the surface, between the rails, at the shoulders between the crest and both slopes and around one third of the way up each slope, shown in Fig. 3. Table 1 provides a description of the soil into which each of the sensors were inserted.

\begin{tabular}{|c|c|c|c|}
\hline $\begin{array}{l}\text { Sensor } \\
\text { No. }\end{array}$ & $\begin{array}{c}\text { Relative } \\
\text { Location }(\mathrm{m})+\end{array}$ & Soil description & Comments \\
\hline 1 & $\begin{array}{l}0 \mathrm{~m} \text { (East) } \\
\text { East Slope: } \\
\text { Toe Area }\end{array}$ & $\begin{array}{l}\text { Dark brown silty CLAY with ash and ballast } \\
\text { gravel }\end{array}$ & $\begin{array}{l}\text { Next to } 2 \text { trees } \\
\text { Near the boundary fence } \\
\text { Ballast gravel probably slipped material }\end{array}$ \\
\hline 2 & $\begin{array}{l}10.5 \mathrm{~m} \text { (East) } \\
\text { East Crest: } \\
\text { Shoulder }\end{array}$ & $\begin{array}{l}\text { Black fine GRAVEL with large to very large } \\
\text { ballast pebbles. Gravel is of ash mainly } \\
\text { granules in size } 2-4 \mathrm{~mm} \text { (or ground up } \\
\text { ballast fines). Organic matter also present. }\end{array}$ & $\begin{array}{l}\text { East shoulder of embankment. } \\
\text { Rail track skewed over to east side and } \\
\text { ballast built up and thickened on this } \\
\text { side. Fairly well maintained. }\end{array}$ \\
\hline 3 & $\begin{array}{l}14.0 \mathrm{~m} \\
\text { Between Rails }\end{array}$ & $\begin{array}{l}\text { Black silty (feels oily too) GRAVEL. Ballast } \\
\text { covering. }\end{array}$ & $\begin{array}{l}200 \mathrm{~mm} \text { west of the east side rail. i.e. } \\
\text { within the rails. }\end{array}$ \\
\hline 4 & $\begin{array}{l}20.5 \text { m (West) } \\
\text { West Crest: } \\
\text { Shoulder }\end{array}$ & $\begin{array}{l}\text { Dark brown gravely silty SAND with large- } \\
\text { very large pebble sized ballast. Grass- } \\
\text { organic matter in soil. }\end{array}$ & $\begin{array}{l}\text { West shoulder of embankment. } \\
\text { West rail removed, ballast old, spent } \\
\text { and not maintained. }\end{array}$ \\
\hline 5 & $\begin{array}{l}32.0 \mathrm{~m} \text { (West) } \\
\text { West Slope: } \\
\text { Toe Area }\end{array}$ & $\begin{array}{l}\text { Dark brown clayey GRAVEL. Gravel from } \\
\text { granules ( } 3-4 \mathrm{~mm}) \text { to large-very large } \\
\text { pebbles of ballast. }\end{array}$ & $\begin{array}{l}\text { Tree roots in soil. Much material in this } \\
\text { location has slipped from above. }\end{array}$ \\
\hline
\end{tabular}

+ Location relates to the position in metres of the nearest resistivity electrode (which were spaced at $0.5 \mathrm{~m}$ )

Table 1. Description of the ground at the locations of the surface moisture probes.

Figure 3. Embankment section showing location of moisture sensors and representative root networks for trees over the embankment flanks. (Schematic shows west side only but similar coverage was observed on both flanks.) 
Const.+Build Mat.

Fig. 4 shows a stiffness model that was constructed by infilling a grid between the stiffness-depth logs using an anisotropic inverse distance weighting between neighbouring grid nodes (Gunn et al. 2011a, 2016b). Interpretation of the embankment model (Fig. 4c) includes soiled modern ballast across the site from the surface to around $0.75 \mathrm{~m}$. Materials underlying the modern ballast in the $\mathrm{SW}$ half of the model include the original engineered ballast pavement comprising angular granodiorite gravel over granodiorite cobbles to depths of about $1 \mathrm{~m}$. Ballast stiffness depends upon its packing and can be highly variable, ranging from 20 MPa to $160 \mathrm{MPa}$. Beneath this, fill in the SW half is dominated by Westbury Mudstone that has degraded to clay in places, which has a stiffness ranging from around $25 \mathrm{MPa}$ to $65 \mathrm{MPa}$; i.e. missing in model only showing stiffnesses above $80 \mathrm{MPa}$ in Fig. 4b. Glaciofluvial sand and gravel occurs beneath the modern ballast over the NE half up to depths of $2 \mathrm{~m}$. The sand is generally uncemented but occasionally the sand was bound within layers around $100 \mathrm{~mm}$ thick by fine, white, powdery non-carbonate cement believed to be gypsum leached from other fill materials. Sandy fill is often stiffer than the Westbury mudstone, generally with stiffnesses around $80-110 \mathrm{MPa}$. Siltstone occurs within the interval from $2-5 \mathrm{~m}$ deep towards the NE end of the model, between $75 \mathrm{~m}$ to $100 \mathrm{~m}$ and also, between $110 \mathrm{~m}$ to $120 \mathrm{~m}$. The siltstone is distributed in fan-shaped lenses with stiffnesses to $120 \mathrm{MPa}$. The morphology of these lenses is consistent with end tipping as the fill progressed away from the SW cutting. Towards the NE, the siltstone just beneath the ballast appears to pinch out into glaciofluvial sand and gravel. A basal, zone below $5 \mathrm{~m}$ is associated with the underlying Branscombe Mudstone Formation bedrock, where stiffness is generally over $100 \mathrm{MPa}$. NE of the large siltstone lens, the bulk of the fill comprises stiff clay, derived either from the Branscombe or the Till. Absence of the clay and mudstone fill in the model showing stiffnesses $>80 \mathrm{MPa}$ indicates that these materials exhibit lower stiffnesses than the underlying source formations, whose original surface is broadly bounded by the $80 \mathrm{MPa}$ iso-surface. Reworking during construction and subsequent in situ deterioration are potential factors causing the lower stiffness of the fill.

Figure 4. East Leake embankment model showing the fill distribution overlying the original formation.

a. CSW profile and MASW survey line locations.

b. 3D Stiffness pseudo-model from the surface wave survey profile interpretations. 
Const.+Build Mat.

Fig. 5 shows ERT sections, which run through the stiffness model of Fig. 4. (Figs. 4b and 5a share the same lateral axis and Fig. $5 \mathrm{c}$ is a transect at $60 \mathrm{~m}$ ). The ballast cover in the $\mathrm{SW}$ produces a layer of high resistivity (> $40 \Omega . m$ ) from the surface to around $1.5 \mathrm{~m}$ deep. From the $0 \mathrm{~m}$ to $40 \mathrm{~m}$ in the longitudinal section, the resistivity of the interval from $1.5 \mathrm{~m}$ to $4 \mathrm{~m}$ is generally below $20 \Omega \mathrm{m}$ and this is consistent with values that would be expected for Westbury Mudstone and clay materials. This zone of low resistivity coincides with low stiffness, low penetration resistance and relatively high friction ratios, and has been classed as a zone of high moisture and low strength. The Westbury fill forms the central low resistivity core between $1.5 \mathrm{~m}$ and $3 \mathrm{~m}$ in the transect (Fig. 5c), where resistivities were as low as $10 \Omega$.m. Lithoclasts of Westbury mudstone were recovered in core samples from this zone that had the structure of a friable shale, and which had also weathered into a soft, dark grey clay. It is believed that this degraded clay provides a secondary infill within the inter- and intra-clast porosity and acts to retain moisture in this core zone. [Feature Dc in Fig. 8 later.]

From the $40 \mathrm{~m}$ to about the $60 \mathrm{~m}$ station, the resistivity of the interval from $1 \mathrm{~m}$ to $3 \mathrm{~m}$ was between $20 \Omega \mathrm{m}$ to $50 \Omega . \mathrm{m}$. This has been interpreted as fill predominantly comprising Westbury Mudstone lithoclasts, possibly with occasional siltstone from the Blue Anchor Formation, which also appears to be present at the base of the station and thickens to about the $70 \mathrm{~m}$ station such that it extends from just beneath the surface to around 4.5 $m$ depth. This high resistivity zone persists longitudinally under the embankment crest over this depth interval towards the $100 \mathrm{~m}$ station. The high resistivity of this zone indicates that the fill has low moisture content and has been shown to be associated with high penetration resistance values and high stiffness values (Fig. 4b). 
Const.+Build Mat.

Figure 5. Resistivity distribution and classification within embankment ground model.

a. Resistivity section across engineering interface between clay and sand-gravel fill zones.

b. Interpretation of fill-bedrock material distribution including material transitions in end-tipped structure.

Non-invasive geophysical surveys have identified internal structures, such as the high-stiffness, high-resistivity siltstone fans, that provide insight into embankment construction and heterogeneity. The embankment appears to contain lens structures with foreset beds comprising materials encountered in the SW cutting.

These are consistent with a process of end tipping leading to larger boulders running downslope to the toe of an advancing embankment to be later infilled by finer materials. These ground models also provide a property framework within which we can build an understanding of the dynamic moisture movement processes driving embankment ageing.

\section{Infiltration and Moisture Transport}

Field data gathered from the surface moisture sensors are presented with the local rainfall from 1st Sept, 2006, which followed a fairly wet late summer, including 2 days in August $\left(2^{\text {nd }}\right.$ and $\left.23^{\text {rd }}\right)$ where the average daily rainfall was $13 \mathrm{~mm}$. Fig. 6 a shows also that September was marked by weather systems delivering heavy rainfall at approximately weekly intervals (ending with $19 \mathrm{~mm}$ on the $29^{\text {th }}$ and $25 \mathrm{~mm}$ on the $30^{\text {th }}$ ). This weather pattern continued through most of October 2006 (with daily rainfall in excess of $10 \mathrm{~mm}$ on the 11th, 19th and 22nd) before a hiatus of around 2 weeks, but which was succeeded by three further stormy phases, (each longer than 4 weeks) over the 2006/07 winter-spring. Heavy rainfall events within these storms are registered by the sensors as a very rapid increase in moisture content, e.g. infiltration and recharge, followed by a more gradual reduction in moisture content, e.g. drainage, evaporation and transpiration. Generally, with the embankment in this state, sensors 2, 3, and 4 located across the crest of the embankment register lower moisture contents than sensors 1 and 5 at the toe of the east and west slopes. Also, sensor 2 on the embankment's east shoulder registers the lowest moisture content, which is most likely due to a combination of its location in well-drained ballast and the protective cover from ash trees. (Sensor 2 registers low moisture contents even after cumulative heavy rainfall events.) Generally, sensor 1 at the toe of the east slope registers the greatest moisture content, which is related to the local soil conditions (silty CLAY) and its location towards 
Const.+Build Mat.

the lower slope. While the absolute volumetric moisture content measured by the sensors is likely to have an

error range circa $+/-10 \% \mathrm{v} / \mathrm{v}$, the temporal variation records credible phases of sustained infiltration

throughout each storm event. Temporary flooding of the drainage channels along the eastern toe provided further evidence that sufficient rainfall was supplied over this period to maintain very high moisture levels within the embankment.

Resistivity is very sensitive to changes in moisture levels and saturation, and because localised moisture increases reduce soil resistivity, the deeper infiltration into the embankment can be visualised using the differences across the transect, of the resistivities recorded during successive surveys. Fig. $6 \mathrm{~b}$ shows resistivity difference images between a baseline survey in July 2006, taken with the embankment in a relatively dry state and at 5 instances in Sept, Nov and Dec 2006, Jan and Mar 2007, approximately coinciding with the breaks between each of the storm events over the 2006/7 winter. Temporal changes on the moisture content sensors are consistent with the spatial changes in the resistivity difference images and focusing upon sensors 1, 3 and 5 , the following correlations can be observed. Moisture levels recorded by sensor 3 (between rails) exhibit the most rapid re-charge / discharge cycles, consistent with the drainage function of ballast. The relative resistivity changes are small at this location, because at all times apart from Nov 2006 they were measured after short periods of drainage during breaks in the rainfall. Moisture levels on sensors 1 (east slope) and 5 (west slope) were relatively low at the time of the Sept and Nov 2006 resistivity surveys, but were then consistently high thereafter. The time lapse resistivity images capture the spatial evolution of the winter moisture ingress as a wetting front that began in Nov 2006, infiltrating deeper into the embankment, leading to substantial saturation in the shallow subsurface within $2 \mathrm{~m}$ of the surface. Deeper infiltration at the toe of the east slope is believed, in part to result from localised run-off and flooding. Whereas, localised infiltration beyond $6 \mathrm{~m}$ deep beneath the west shoulder is believed to be due to a relatively permeable flow path.

Figure 6. Spatial and temporal control of surface infiltration and internal ground water transport on the dynamic moisture content distribution within the embankment.

a. Dynamic near surface moisture content variation in response to daily precipitation.

b. Ingress observed as wetting fronts infiltrating deeper into embankment in response to repeated phases of persistent, heavy rainfall. 
Const.+Build Mat.

\section{Moisture Content and Saturation within the Embankment}

By attributing a reference resistivity to fully saturated fill materials and following the methods by Chambers et al. (2014), resistivity difference images were also transformed into estimates of moisture content and saturation (as shown in Fig. 5c). Even though uncertainty in the resistivity-moisture content transformation leads to errors in the absolute moisture content values, the time-lapse images provide quite credible changes in the dynamic moisture distribution. The images in Fig. 7 show the dynamic saturation changes within the embankment during the $2009 / 10$ winter ingress. In the near surface across the crest and flanks, saturation levels within the July 2006 baseline image are circa 10\%, whereas the low resistivity core appears to be close to full saturation. In contrast to the July 2006 baseline, there are minor differences in saturation throughout the earthworks in Oct 2009, prior to progressive increases in relative saturation within $2 \mathrm{~m}$ of the surface and deeper into the embankment beneath the east toe and the west shoulder in the following months. Guelph Permeameter tests on pit floors in the ballast and sub-ballast yielded hydraulic conductivity values between $10^{-3}$ and $10^{-2} \mathrm{~ms}^{-1}$, suggesting the potential for rapid infiltration (minutes / hours) through the pervious fill materials (sand and gravel) $0.5-1 \mathrm{~m}$ below the surface. Note, up to 4 -fold increases in saturation on the crest either side of the rail track and lower down on both east and west slopes by March 2010, for example suggesting saturations of circa $40 \%$. Saturation of the central core changes little, which is consistent with it being near full saturation, and possibly relatively impervious. Interestingly, the pattern of moisture increases beneath the west shoulder around this central core are consistent with perching and lateral flow about a low permeability core, with further lateral flow and under-drainage deeper into the embankment. Further perching at the base embankment is also possible above the formation.

Figure 7. Dynamic saturation distributions within the embankment arising from the winter 2009-10 ingress.

\section{Evolution of Earthworks Fabric and Ageing Processes}

Materials dug out of cuttings and tipped into the earthworks, were compacted by small steam locomotives causing deformation of the aggregate clasts. Impact damage, especially at point contacts has caused shearing, plastic and brittle deformation of clasts leading to disaggregation along bedding planes and micro-fractures, 
Const.+Build Mat.

resulting in the production of finer material, see A in Fig. 8. Shearing along clast laminae and inter-clast boundaries (B) increases porosity, opening the fill matrix to percolating groundwater, leading to chemical alteration. The open Westbury Mudstone fill is rich in iron pyrites and evaporites such as gypsum and anhydrite, through which oxygenated groundwater would have percolated. In situ oxidisation of the pyrite $\left[\mathrm{FeS}_{2}+\mathrm{a} \cdot \mathrm{O}_{2}+\mathrm{b} \cdot \mathrm{H}_{2} \mathrm{O} \rightarrow \mathrm{Fe}(\mathrm{OH})_{3}+4 \mathrm{H}_{\mathrm{aq}}^{+}+2\left(\mathrm{SO}_{4}\right)^{2-}{ }_{\text {aq }}\right]$ liberated sulphate, which dissolved in the ground water to produce weak sulphuric acid. The seasonal moisture supply and subsurface movement of this weakly acidic groundwater would have driven the dissolution and precipitation throughout the fill. Infiltration from storm events would have mobilised the ferrous and sulphate ions throughout the embankment, hence driving secondary mineralisation. Exposure to groundwater causes hydration of anhydrite to gypsum $\left(\mathrm{CaSO}_{4}+2 \mathrm{H}_{2} \mathrm{O} \rightarrow\right.$ $\left.\mathrm{CaSO}_{4} \cdot 2 \mathrm{H}_{2} \mathrm{O}\right)$, resulting in a significant increase in molar volume (38.5 \%), in turn causing expansion and disruption of the rock fabric. For example, the disrupted clast lamination (C) and secondary development of minerals $\left(D_{G}, D_{H}\right.$ and $\left.D_{C}\right)$ in Fig. 8 may have originally been caused by heave from anhydrite hydration. Hydration would have occurred during wetting early in the embankment's lifecycle and most of the original anhydrite has since been removed. $\mathrm{CaSO}_{4}$ originally leached from the solid fabric was re-precipitated as gypsum within the primary and secondary porosity between and within the lithoclasts. Jarosite $\left[\mathrm{K} \mathrm{Fe}^{3+}\left(\mathrm{SO}_{4}\right)_{2}\right.$ $(\mathrm{OH})_{6}$ ] was also formed during the alteration as a result of interactions between the sulphate-rich pore fluids and the potassium-rich illite clay. Crystal growth along fracture networks that originally transported the water has resulted in heaving apart of adjacent clasts (analogous to ice heave). It is likely that dissolution in situ, mobilisation and re-precipitation of soluble mineral phases occurred repeatedly in response to seasonal wetting and drying periods throughout the lifetime of the embankment.

Figure 8. Thin sections of Westbury Mudstone fill taken from the bottom of the low resistivity 'core' zone in Fig. 5c.

Stress relief in the mudstone clasts resulted in exfoliated laminae and a fabric cut by irregular micro-fractures, within which percolating ground water mobilised disaggregated clay fines, Fig. 9. Further micro-voiding developed as primary minerals dissolved out of the fabric and fines were removed, with some voids ghosting former locations of lath crystals, see E in Fig. 9. Water infiltrating the fissure network deposited disaggregated 
Const.+Build Mat.

clay fines and secondary growths of micro-saccharoidal gypsum and jarosite, Dc in Fig 8 and F, G in Fig. 9. The inset in Fig. 9 shows a typical secondary gypsum rosette common throughout the Westbury fill.

Figure 9. Thin sections of Westbury Mudstone fill near the base of the embankment.

So, geophysical monitoring provides a ground model including the hydrogeological processes that would contribute to long term ageing of the embankment. Observations on thin sections produced from core taken from the embankment indicate that these processes would have acted within an open fabric and would have caused a further opening of that fabric. Cycles of repeated dynamic loading, percolation of water around a framework of lithoclasts and along fracture networks appear to have contributed to deterioration of embankment condition. Deterioration resulting from the disintegration of lithoclasts into finer particles and the wash out of fines, chemical alteration such as oxidation of sulphides and related breakdown of argillaceous minerals (in mudstones), dissolution of soluble minerals on wetting, secondary mineralisation and reprecipitation on drying.

\section{Discussion: Non-invasive Geophysics for Long Term Monitoring}

While non-invasive CSW/MASW and ERT are used for holistic characterization of earthwork structure and dynamic condition, they tend to be used in isolation. However, the hydrological and mechanical information delivered 'on demand' from combined MASW and ERT images at high spatial resolution can form the basis of new risk-based asset management practice. Dynamic subsurface properties and the development of the ground conditions identified as the precursors, or triggers leading to future failure would be routinely monitored. Such scheme could be built around the conceptual shrinkage curve, Fig. 10. Assuming that in situ moisture contents range from the 'shrinkage' to the 'plastic' limit under current UK climate conditions, but which could increase under wetter, or decrease under drier climates. This information would be supplied from low cost real-time, remote monitoring platforms either retrofitted of built-in during new construction. PRIME (Gunn \& Chambers 2015) is an example of a very low cost system combining ERT technology with data telemetry and web portal access designed for monitoring the internal condition of geotechnical assets. 
Const.+Build Mat.

Distributed acoustic sensing of time-varying strains using fibre optic cables (Parker et al. 2014) is approaching

the metric-scale sampling required for via seismic monitoring of transportation and utility infrastructure. An asset condition classification scheme would be based upon the consistency of fine grained fill materials, onto which moisture content ranges would be mapped (for example adapted to the geographic distribution of source material plasticities). The example in Fig. 10 is for Mercia Mudstone fill, which has very high porosity ranging from $49-55 \%$ and a low dry density of around $1.3 \mathrm{Mg} \cdot \mathrm{m}^{-3}$, plastic and liquid limits between $34-40 \%$ and 57-67\% GMC respectively. Fig. 10 also shows the variation with moisture content of the resistivity (inline with compaction) mapped between the shrinkage and plastic limits. MASW field tests yielded shear wave velocities of circa $120 \mathrm{~m} . \mathrm{s}^{-1}$ at in situ moisture contents of around $24 \% \mathrm{GMC}(0.35 \mathrm{VMC})$ but as low as $80 \mathrm{~m} . \mathrm{s}^{-1}$ at full saturation at approx. $40 \% \mathrm{GMC}(0.5 \mathrm{VMC})$. Early warning of ground conditions that could trigger future instability would be based upon semi-quantitative moisture content images and groundwater movement from time-lapse ERT. Detection of threshold moisture contents either above the plastic limit, i.e. resistivities $<8$ $\Omega . m$ suggesting $\mathrm{GMC}>32 \%$ ( $0.45 \mathrm{VMC}$ ) or below the shrinkage limit, i.e. resistivities $>30 \Omega . \mathrm{m}$ suggesting $\mathrm{GMC}$ $<12 \%(0.2 \mathrm{VMC})$ would trigger early interventions, such as an inspection focused within a zone identified in the subsurface moisture content image. The ultimate decision to intervene may rely upon associated MASW measurements through the ground, e.g. in this case where velocities $<90 \mathrm{~m} \cdot \mathrm{s}^{-1}$ at the plastic limit would raise concerns relating to deformation and velocities $>140 \mathrm{~m} \cdot \mathrm{s}^{-1}$ at the shrinkage limit would raise concern in relation to crack developments.

Figure 10. Asset monitoring concept combining electrical and seismic geophysical methods.

Interventions are likely to be designed on a case by case basis and could include further focused surveys over zones of very high moisture content identified by ERT images. The intervention tool kit would include focused 2D and 3D MASW surveys delivering stiffness ground models and providing a proxy for shear strength. This is completely consistent with the drive towards low-cost maintenance regimes, replacing costly repair/refurbishment with prioritised, targeted interventions, where increasing use of new soft ground improvement practices is envisaged. For example, ERT and MASW surveys could complement electrokinetic 
Const.+Build Mat.

1 osmosis or vegetation management interventions as a means of monitoring the water removal and associated

2 ground stiffness improvement.

3 Inevitably this will lead to more selective maintenance prioritisation increasingly supported by information

4 delivered from real-time remote monitoring platforms, for example, supplying geophysical images. Potentially,

5 interrelated geotechnical parameters of porosity, saturation, density, suction and stiffness can be inverted via

6 joint algorithms that define their coupled control over shear wave velocity and electrical resistivity. Resulting

7 time-series geophysical property images can potentially facilitate quantitative and fully automated earthwork

8 internal condition assessment. Back-catalogues from routine monitoring programmes will aid understanding of

9 the current condition and the rate of deterioration of critical geotechnical assets across UK transportation and 10 utility networks. In this manner rapid non-invasive geophysics would contribute to our understanding of the 11 ultimate life-cycle of our transport and major utility networks.

\section{Acknowledgements}

14 This paper is published with the permission of the Executive Director of the British Geological Survey (NERC).

15 The authors gratefully acknowledge the work of Richard and William Tinsley of Surface Waves Surveys Ltd.

16 who gathered the CSW field data. Finally, we also gratefully acknowledge the Great Central Railway

17 (Nottingham) Ltd. for allowing access on to the East Leake embankment. This paper has been made possible 18 via funding from a number of sources including (inter alia): BGS (NERC) Scientific Programme, RCUK iSMART 19 (EP/K027050/1) and the emda ALERT-ME (Project No. 0650). 


\section{$\underline{\text { References }}$}

Bergamo, P., Dashwood, B., Uhlemann, S., Swift, R., Chambers, J.E., Gunn, D.A. \& Donohue, S. 2016a. Time-lapse monitoring of climate effects on earthworks using surface waves. Geophysics 81, (2), 1-15.

Bidder, F.W. 1900. The Great Central Railway Extension: Northern Division. ICE, Vol. CXLII, Session 1899-1900. Part IV, Paper 3227, 1-22.

Brees, S.C. 1841. A glossary of civil engineering comprising its theory and modern practice. London, Tilt and Bogue, 310p.

Brunet P., Clement R. \& Bouvier C. 2010. Monitoring soil water content and deficit using Electrical Resistivity Tomography (ERT) - A case study in the Cevennes area, France. Journal of Hydrology 380, 146-153.

Cassiani G., Godio A., Stocco S., Villa A., Deiana R., Frattini P. and Rossi M. 2009. Monitoring the hydrologic behaviour of a mountain slope via time-lapse electrical resistivity tomography. Near Surface Geophysics 7, 475-486.

Chambers, J., Gunn, D., Wilkinson, P. B., et al. 2014. 4D electrical resistivity tomography monitoring of soil moisture dynamics in an operational railway embankment. Near Surface Geophysics, 12, 61-72

Dijkstra, T., Dixon, N., Crosby, C., Frost, M., Gunn, D., Fleming, P., \& Wilks, J. 2014. Forecasting infrastructure resilience to climate change. Proceedings of the ICE-Transport, 167(5), 269-280.

Donohue S., Gavin K. and Tolooiyan A. 2011. Geophysical and geotechnical assessment of a railway embankment failure. Near Surface Geophysics 9, 33-44.

Dunnicliff, J. 2012. Chapter 95; Types of geotechnical instrumentation and their usage. In: Burland, J. et al. Ed. ICE manual of geotechnical engineering. ICE, London, 1379-1403.

Foti S. 2003. Small strain stiffness and damping ratio of Pisa clay from surface wave tests. Geotechnique, 53, $455-461$.

Glendinning, S., Helm, P.R., Rouainia, M., Stirling, R.A., Asquith, J.D., Hughes, P.N., Toll, D.G., Clarke, D., Powrie, W., Smethurst, J., Hughes, D., Harley, R., Karim, R., Dixon, N., Crosby, C., Chambers, J., Dijkstra, T., Gunn, D., Briggs, K. \& Muddle, D. 2015. Research-informed design, management and maintenance of infrastructure slopes: development of a multi-scalar approach. In IOP Conference Series: Earth and Environmental Science (Vol. 26, No. 1, p. 012005). IOP Publishing, 22p.

Gunn, D.A. et al. 2011a. Embankment stiffness characterisation using MASW and CSW methods, Proc. 11th Int. Conf. Railway Engineering, London, 2011.

Gunn D.A., Williams, G., Raines, M.G., Busby, J.P., Williams, J.D.O. \& Pearson, S.G. 2011b. Comparison of surface wave techniques to estimate shear wave velocity in a sand and gravel sequence: Holme-Pierrepont, Nottingham, UK. QJEGH, 2012, v. 45, p. 139-160.

Gunn, D.A., Chambers, J.C., Uhlemann, S., Wilkinson, J.B., Meldrum, P.I., Dijkstra, T., Haslam, E., Kirkham, M., Wragg, J., Holyoake, S., Hughes, P.N. Hen-Jones, R. \& Glendinning S. 2015a. Moisture monitoring in clay embankments using electrical resistivity tomography. Construction and Building Materials, 92, pp.82-94.

Gunn, D.A., Donohue, S., Dashwood, B.A.J., Bergamo, P., Raines, M.G., Uhlemann, S. and Chambers, J.E. $2015 b$. Earthworks ground model development using surface wave surveys. Proc. XVI ECSMGE, Edinburgh, 13-17 Sept 2015, 3541-3546.

Gunn, D.A. \& Chambers, J.E. 2015. Proactive Infrastructure Evaluation and Monitoring (PRIME). Remote Monitoring of Geotechnical Assets. Geotechnica 2015. Banbury, 8th July, 2015.

Gunn, D. et al. 2016a. Aged embankment characterisation using non-invasive geophysics. ISSHMII Proc. 7th Int. Conf. on Structural Health Monitoring, Belfast, 26-27th May, 2016.

Gunn, DA, Dashwood, BAJ, Bergamo, P \& Donohue, S. 2016b. Aged embankment imaging and assessment using surface waves. Forensic Engineering V169, Nov 2016, 149-165. 
Hughes, D., Karim, M.R., Briggs, K., Glendinning, S., Toll, D., Dijkstra, T., Powrie, W. and Dixon, N. 2015. A Comparison of numerical modelling techniques to predict the effect of climate on infrastructure slopes. Géotechnique, 65(12), pp.995-1009.

Joh, S.-H. (1996). FIT7: Program for forward modelling analysis, inversion analysis and time trace generation. Univ. of Texas, USA.

Loke, M.H., and Barker, R.D. 1995. Least-squares deconvolution of apparent resistivity pseudosections. Geophysics, 60 , 1682-1690.

Loke, M.H., Acworth, R.I., Dahlin, T. 2003. A comparison of smooth and blocky inversion methods in 2D electrical imaging surveys. Exploration Geophysics 34, 182-187.

Mazzanti, P. 2012. Remote monitoring for deformation. An overview of the seven methods described in previous GINs. Geotechnical News, 30(4), 24.

Meigh, A.C. 1987. Cone penetration testing. Methods and interpretation. CIRIA Ground Engineering Report: In situ testing, Butterworths, London, 141p.

Menzies, B.K. 2001. Near-surface site characterisation by ground stiffness profiling using surface wave geophysics. Instrumentation in Geotechnical Engineering. H.C.Verma Commemorative Volume. Eds. K.R. Saxena and V.M. Sharma. Oxford \& IBH Publishing Co. Pvt. Ltd., New Delhi, Calcutta, pp 43-71.

Parker, T., Shatalin, S. \& Farhadiroushan, M. 2014. Distributed acoustic sensing - a new tool for seismic applications. First Break, 32, Feb 2014, 61-69.

Perry, J.G. et al. 2003. Infrastructure embankments - condition appraisal and remedial treatment. CIRIA Publ. C592. 245p

Raines, M.G., D.A. Gunn, Morgan, D.J.R., Williams, G. and Williams, J.D.O. \& Caunt, S. 2011. Refraction microtremor (ReMi) to determine the shear wave velocity structure about a mineshaft. Q.J.E.G.H. 44, pp 211-220.

Reeves, G.M., Sims, I. \& Cripps, J.C. 2006. Clay materials used in construction. Geol. Soc. Eng. Geol. Sp. Publ. 21. London, $525 p$.

Selig, E.T. \& Waters, J.W., 1994. Rail geotechnology and substructure management. Thomas Telford Ltd., London. 446p

Shevnin V., Mousatov A., Ryjov A. and Delgado-Rodriquez O. 2007. Estimation of clay content in soil based on resistivity modelling and laboratory measurements. Geophysical Prospecting 55, 265-275.

27 Skempton, A.W., 1996. Embankments and cuttings on the early railways. Construction History, 11: 33-39.

28 Stevenson, D., 1886. The principles and practice of canal and river engineering. $3^{\text {rd }}$ Ed. Edinburgh University Press, $406 p$. 


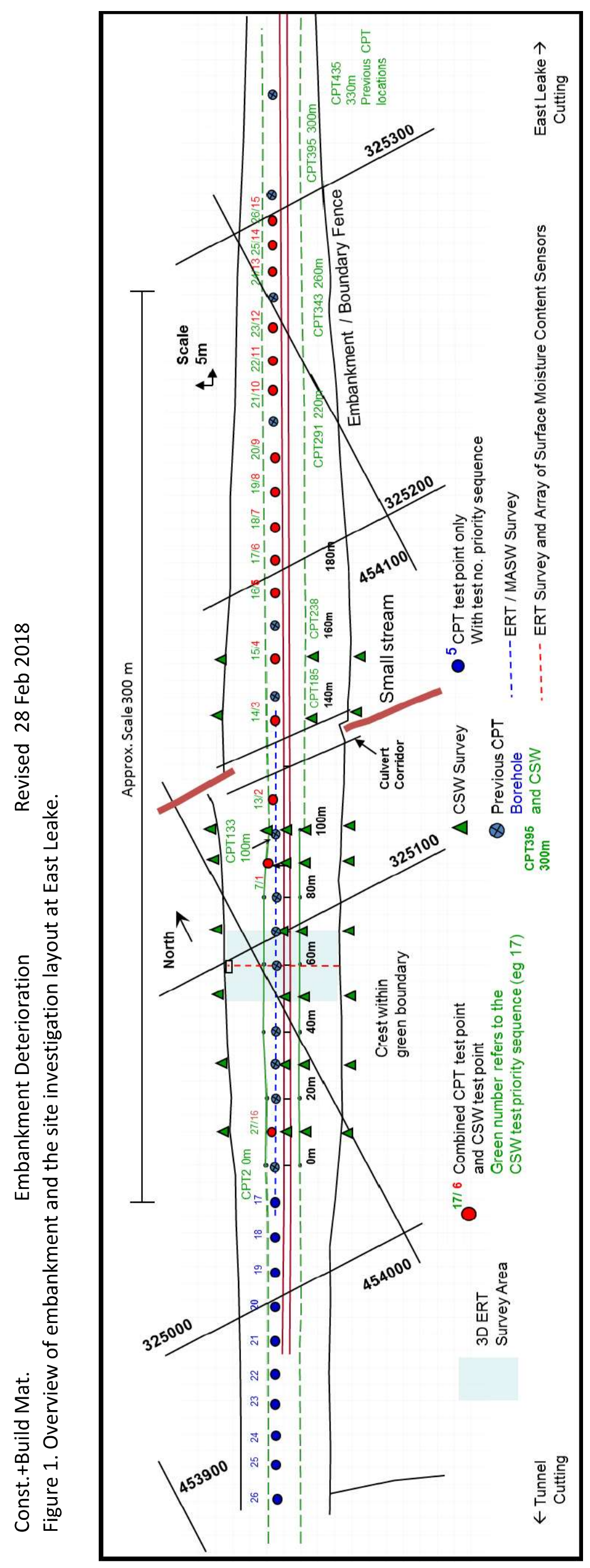




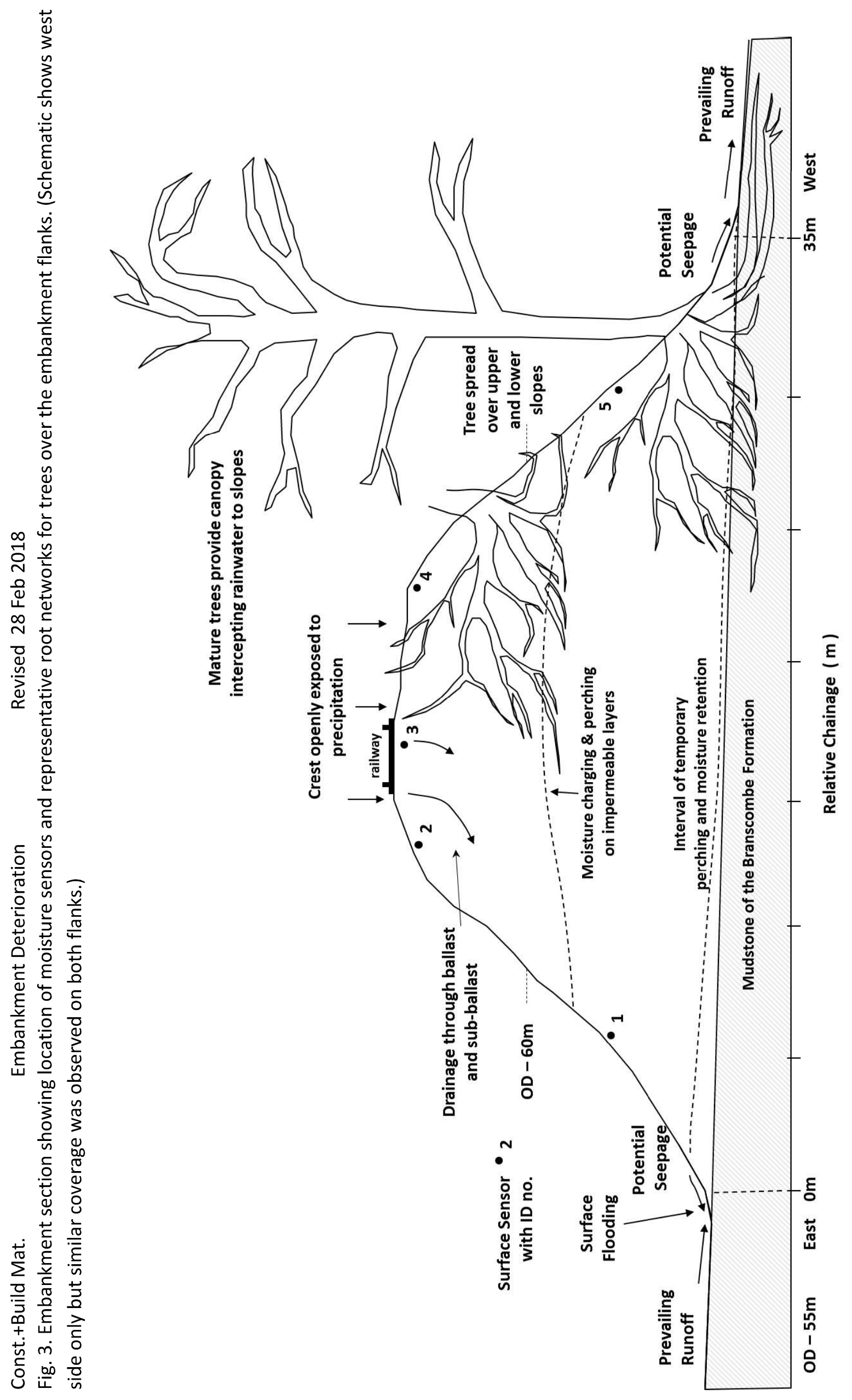



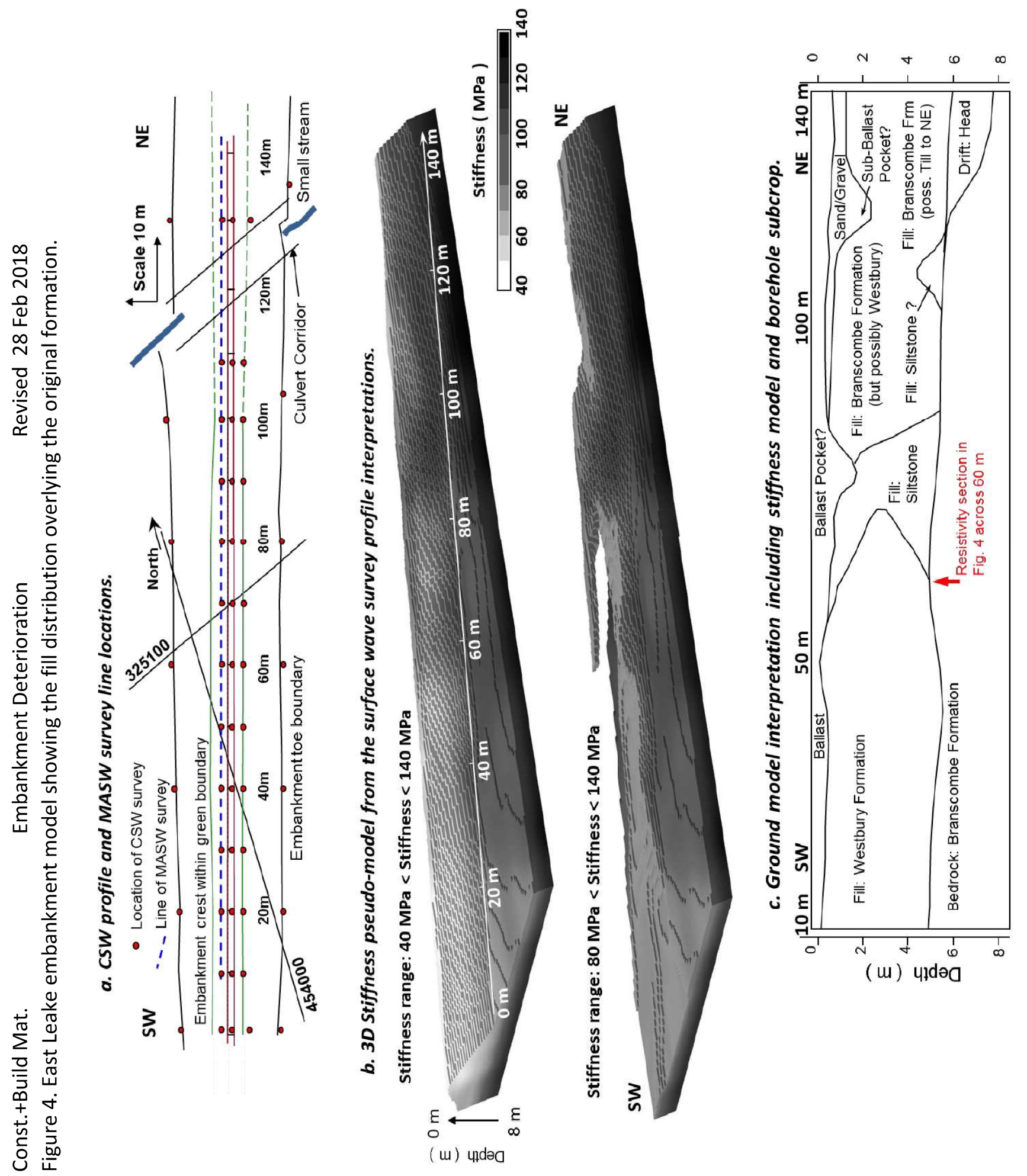

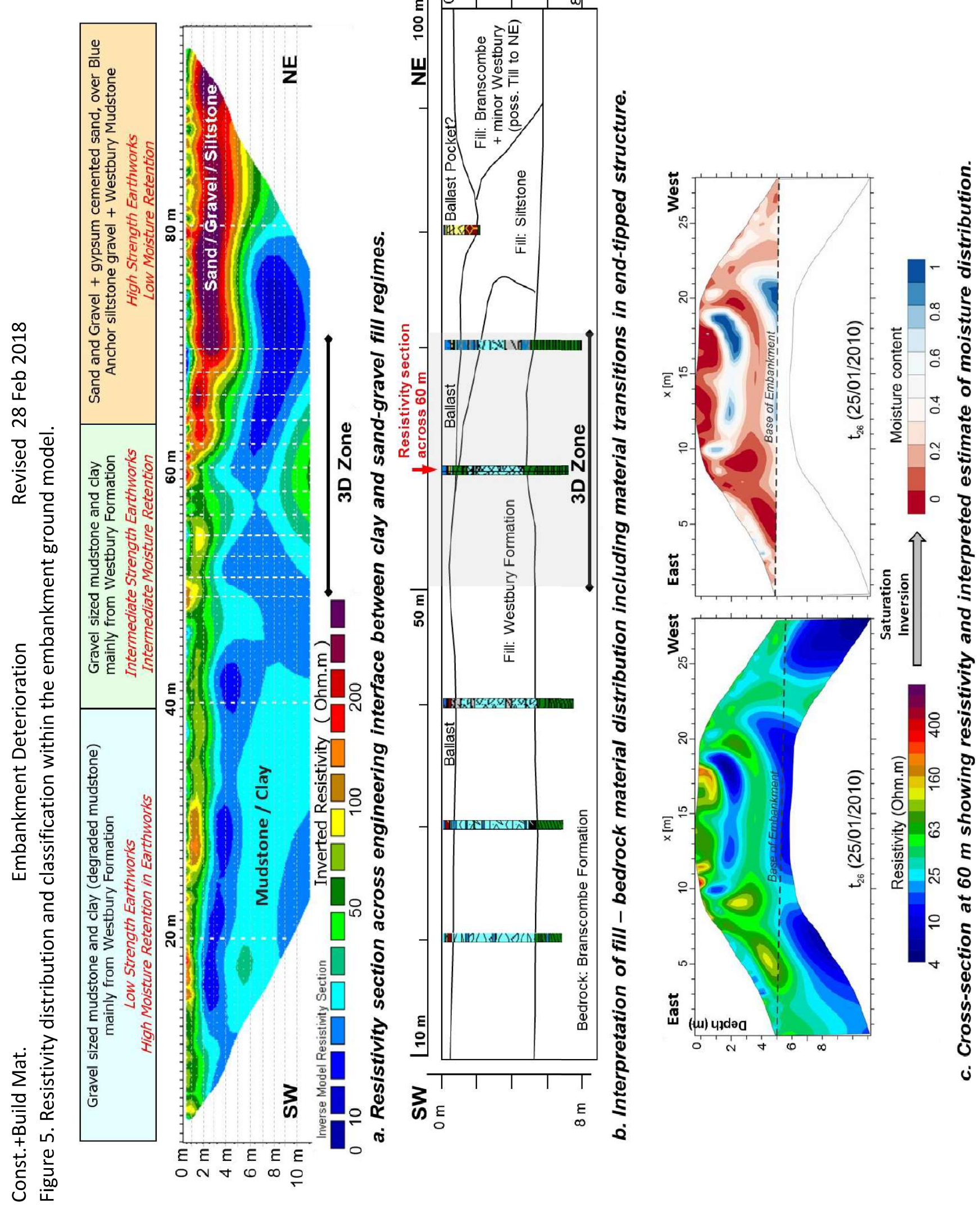

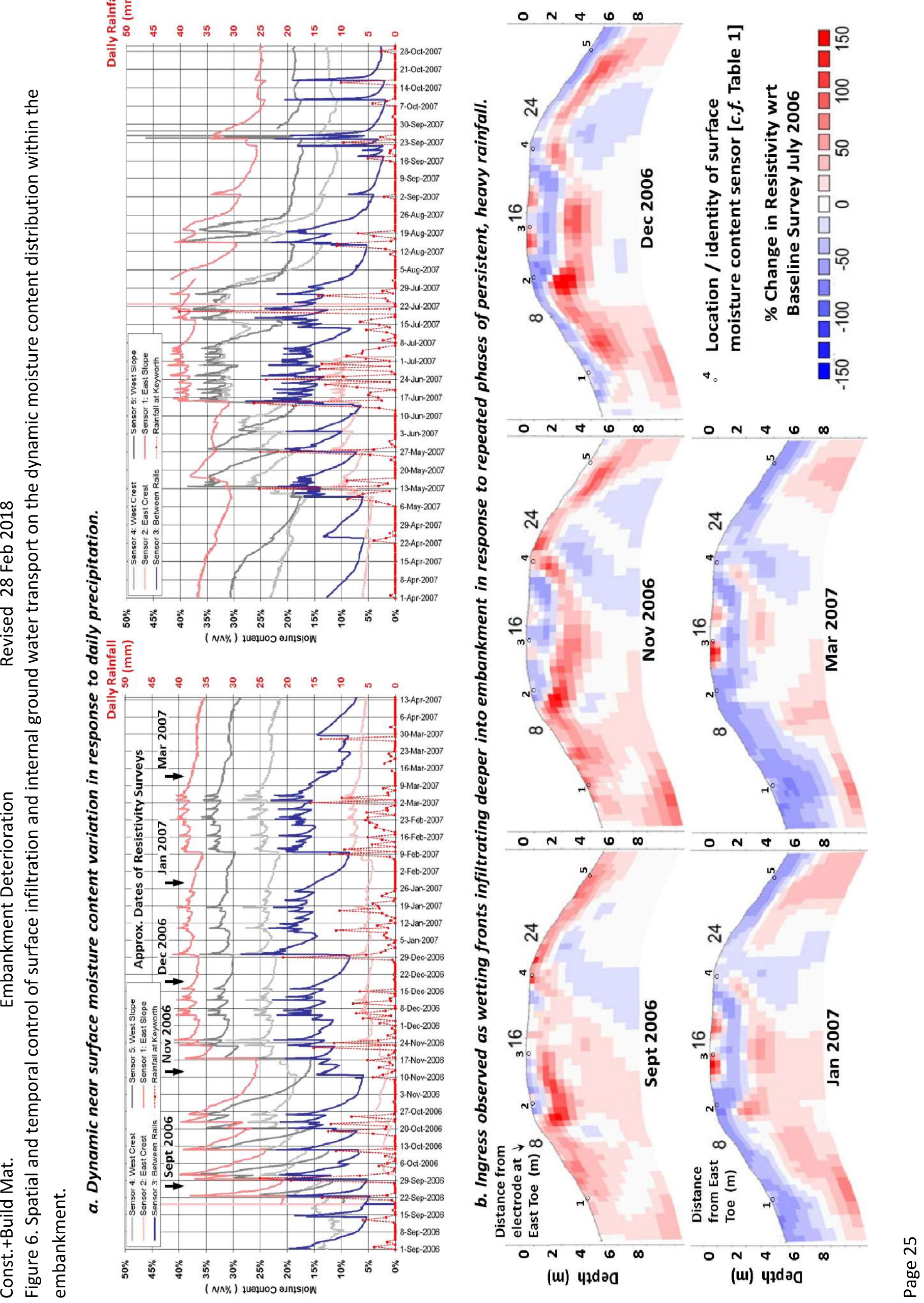

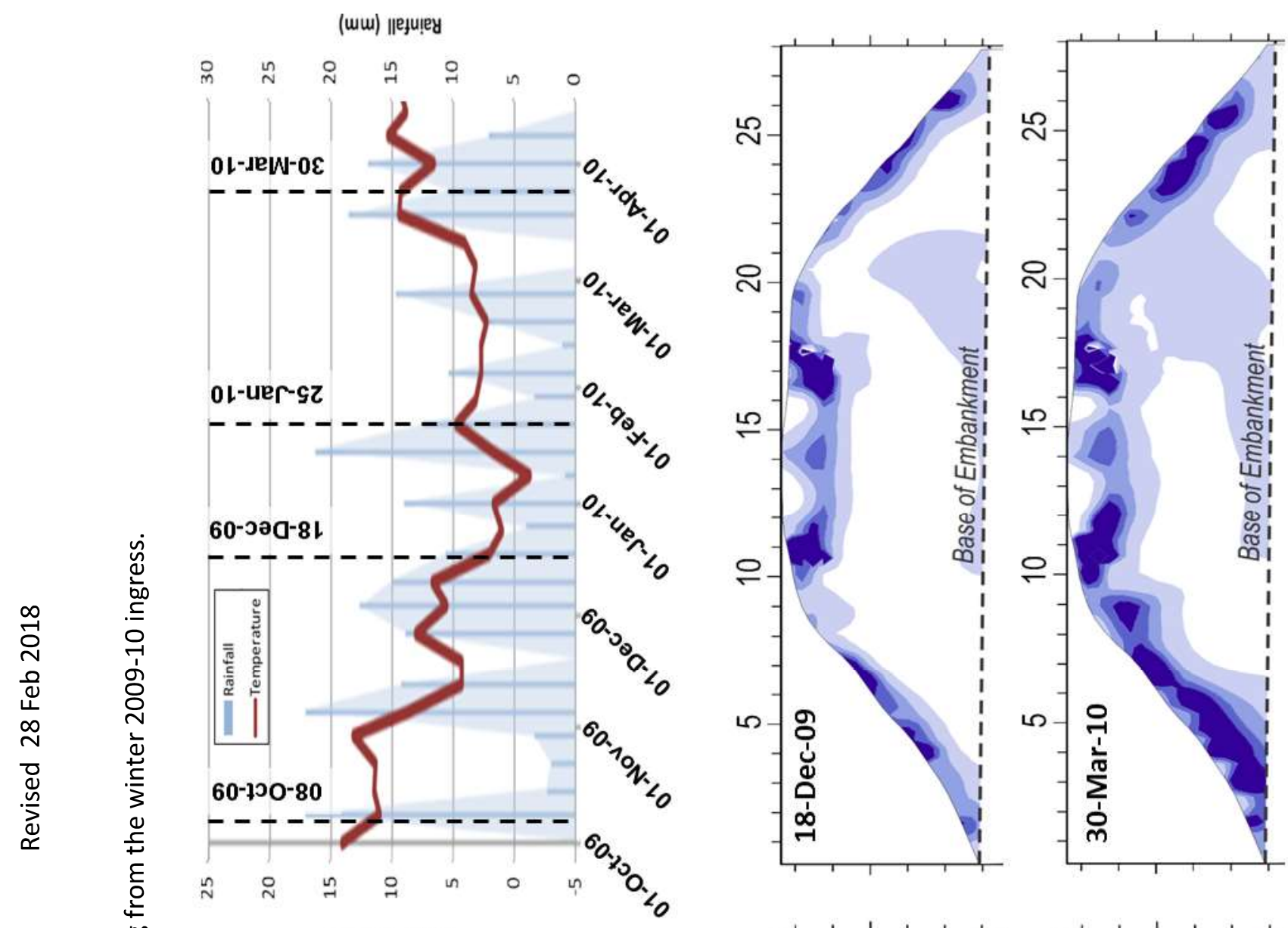

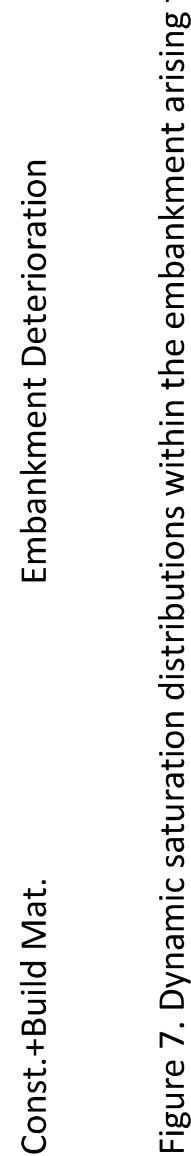
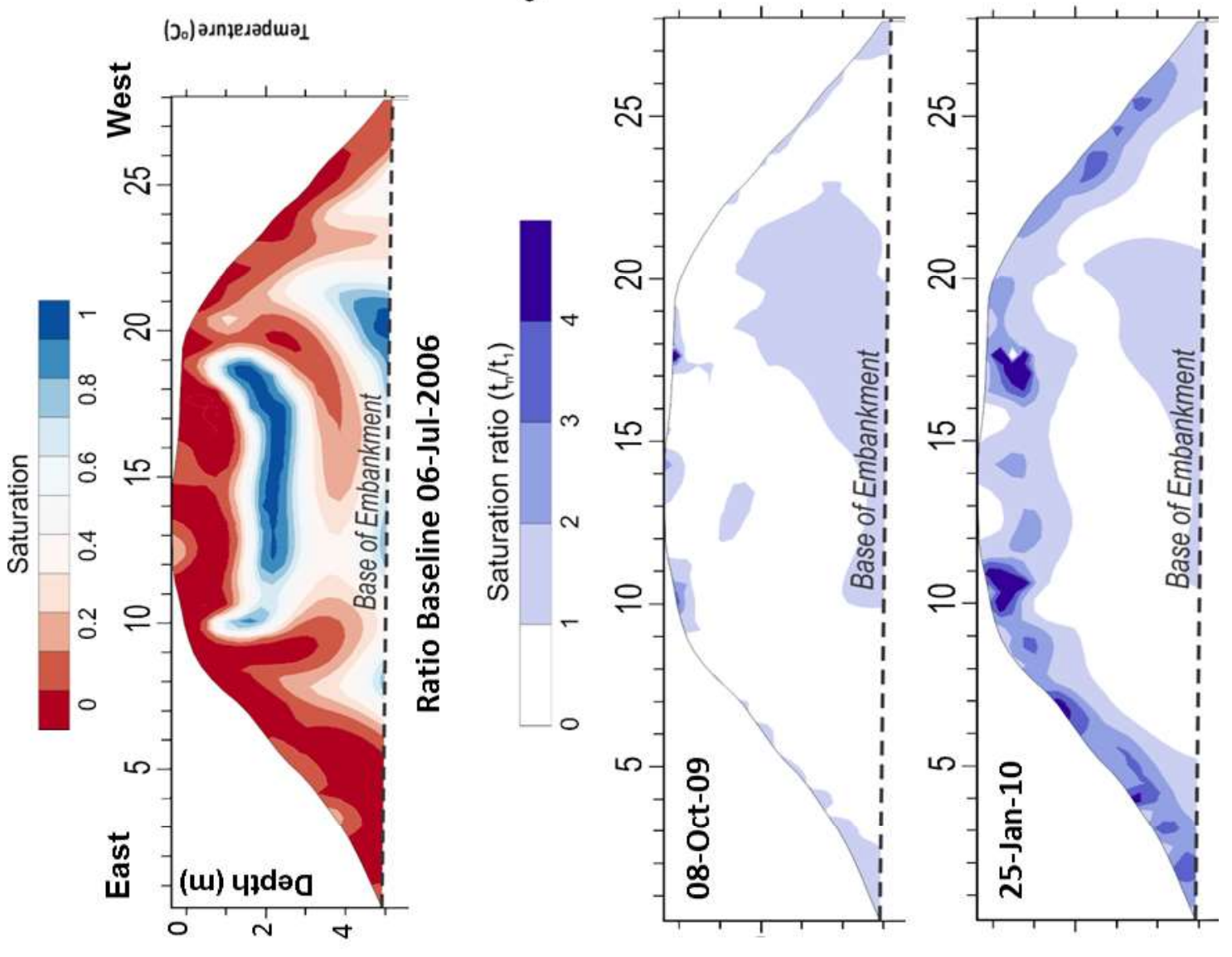


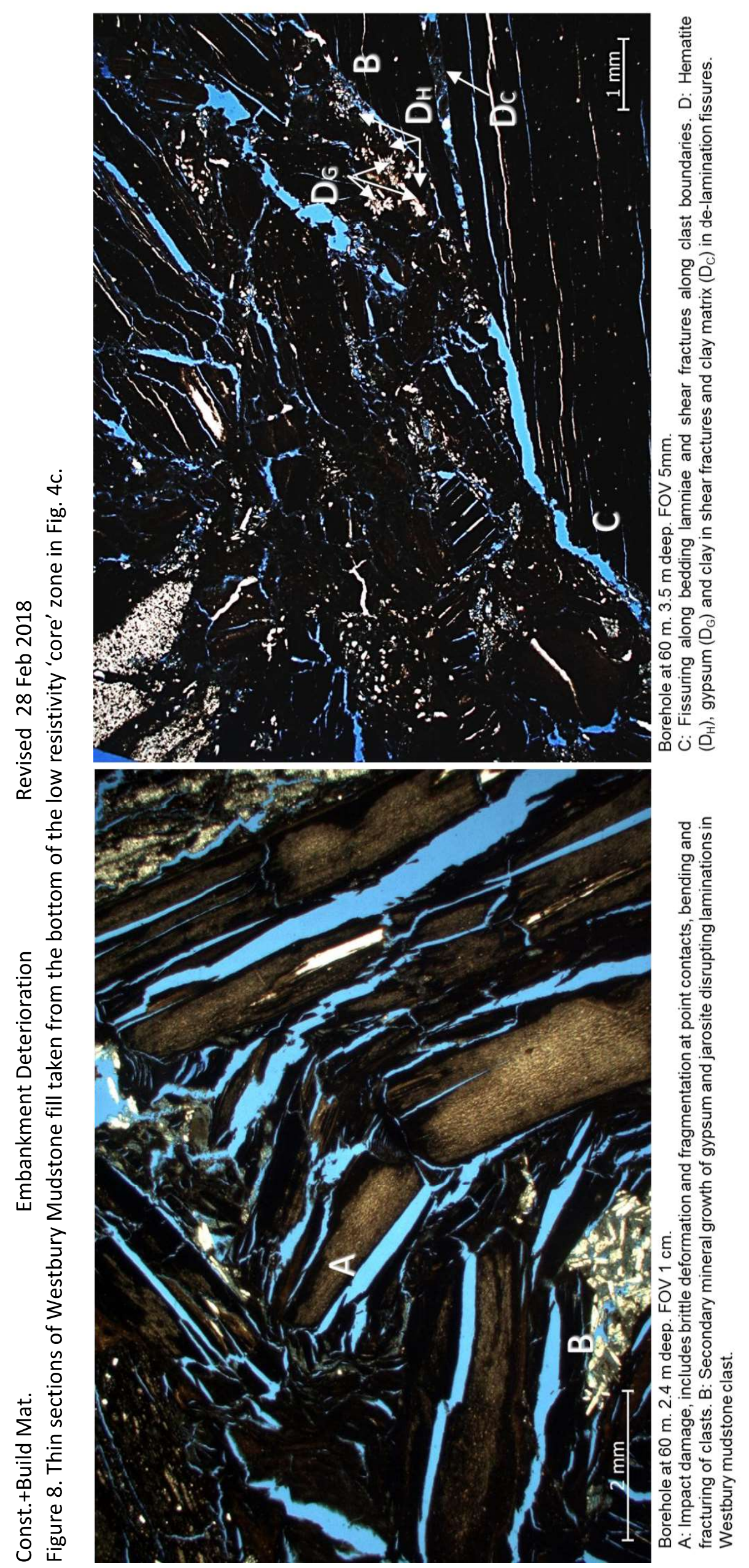




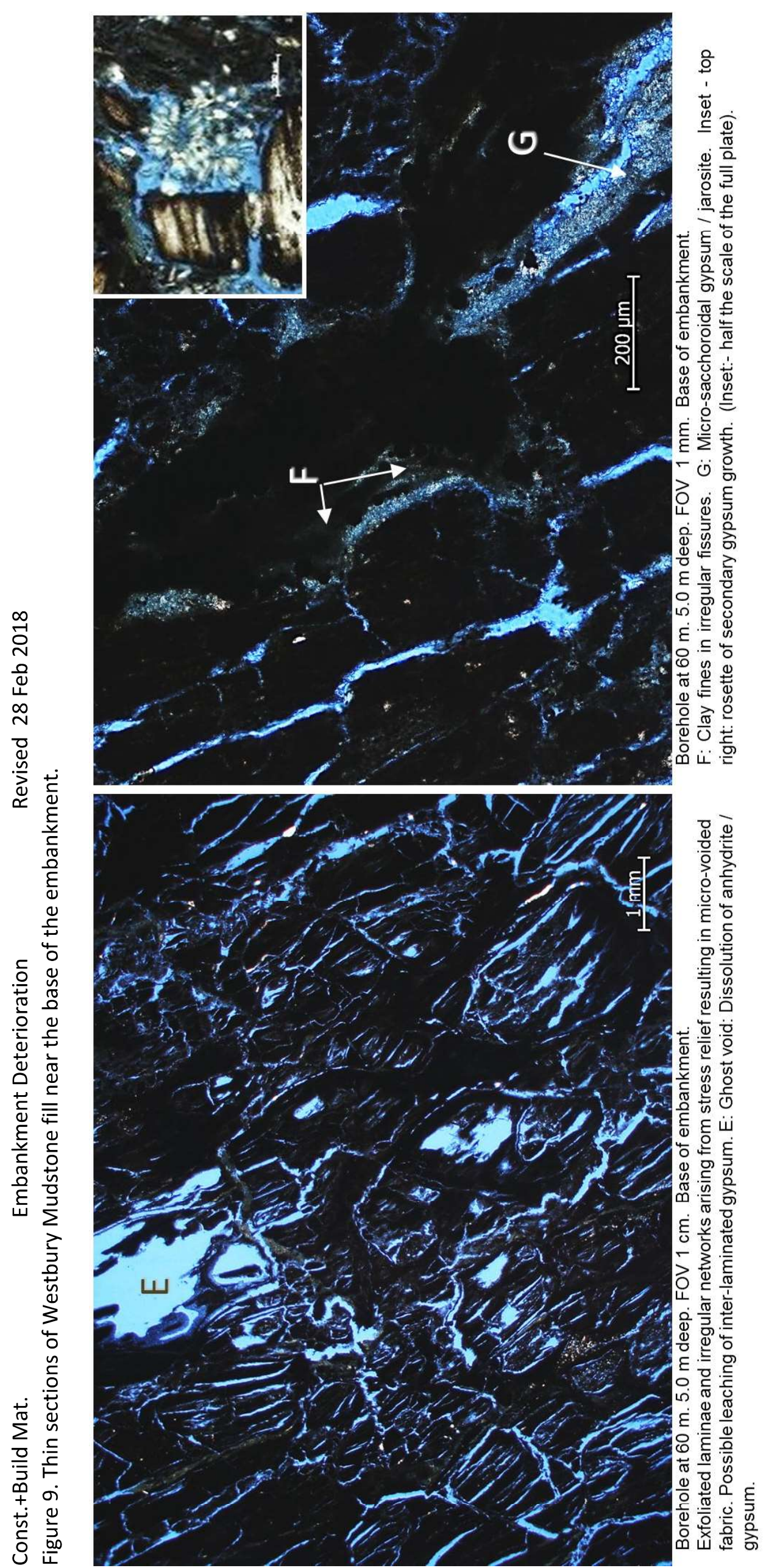




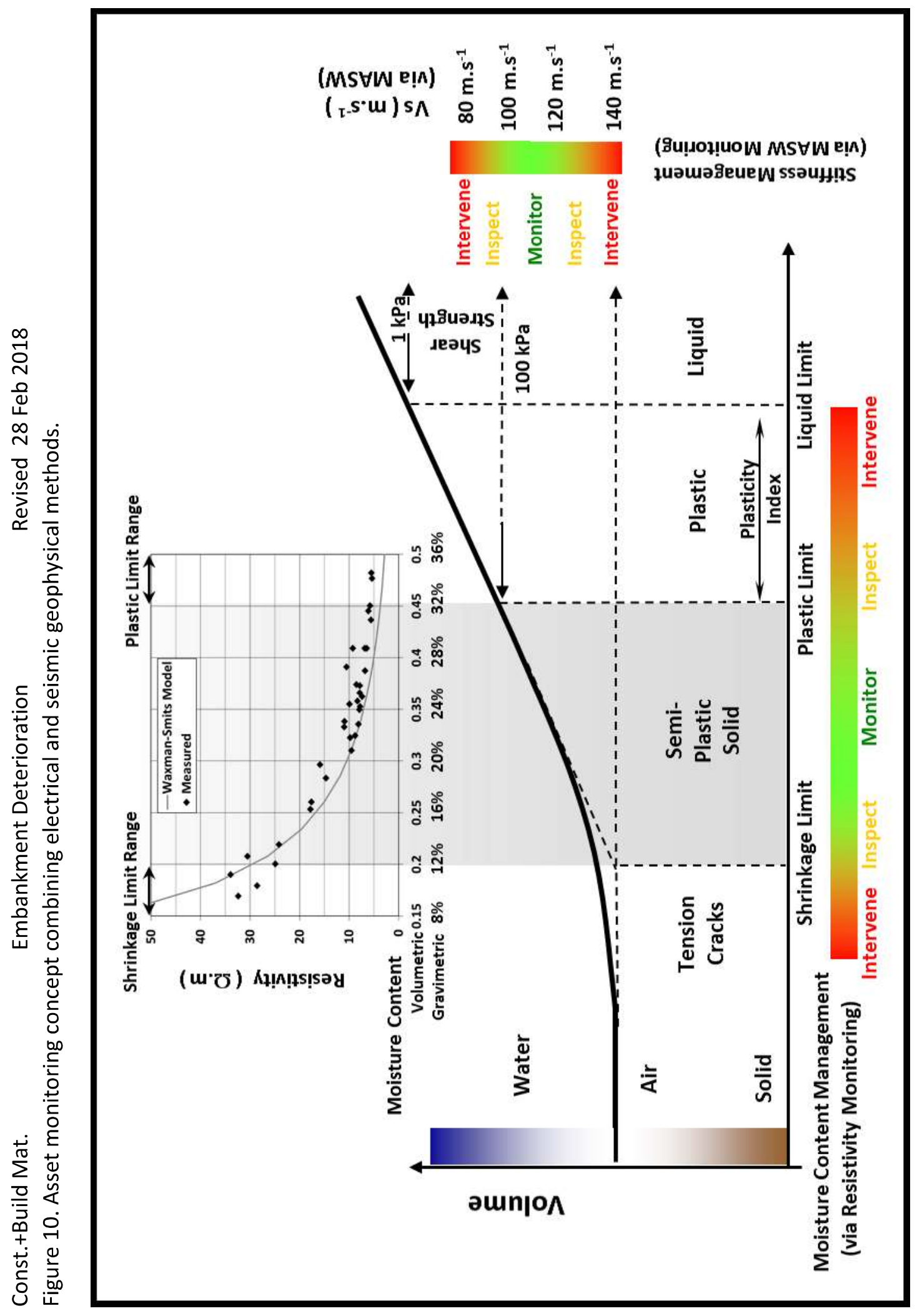

